IRA-International Journal of Management \& Social Sciences

ISSN 2455-2267; Vol.04, Issue 03 (2016)

Pg. no. 579-589

Institute of Research Advances

http://research-advances.org/index.php/RAJMSS

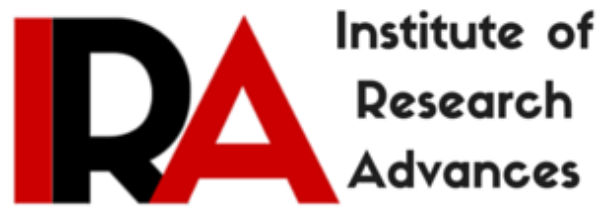

\title{
Feminist Philosophical Thought in Colonial India
}

\author{
Dr. Archana Malik-Goure \\ Assistant Professor, \\ Department of Philosophy, \\ University of Mumbai, India.
}

Type of Review: Peer Reviewed.

DOI: http://dx.doi.org/10.21013/jmss.v4.n3.p8

\section{How to cite this paper:}

Malik-Goure, A. (2016). Feminist Philosophical Thought in Colonial India. IRAInternational Journal of Management \& Social Sciences (ISSN 2455-2267), 4(3), 579589. doi:http://dx.doi.org/10.21013/jmss.v4.n3.p8

(C) Institute of Research Advances

(c)) EY-NC

This work is licensed under a Creative Commons Attribution-Non Commercial 4.0 International License subject to proper citation to the publication source of the work.

Disclaimer: The scholarly papers as reviewed and published by the Institute of Research Advances (IRA) are the views and opinions of their respective authors and are not the views or opinions of the IRA. The IRA disclaims of any harm or loss caused due to the published content to any party. 




These fragrant flowers I offer thee. Strung in a garland of rhymes...

Each poetic blossom is full of glee. Their fragrance brings peace sublime. Advice that is amusing. Easy to understand and charming ....

Simple moral education Knowledge that appeals to emotion....

Savitribai Phule (Kavya Phule)

Savitribai Phule $\left(3^{\text {rd }}\right.$ January $1831-10^{\text {th }}$ March 1897) was a social reformer of nineteenth century India (Maharashtra), capable teacher, leader, thinker, writer, and committed companion to her husband. Savitribai Phule is credited with being the first native teacher of girls in Maharashtra. She also happens to be the first modern, radical, Marathi poet. For her work for women education many people called her as Jananajyoti (Flame of education) and Krantijyoti (Flame of Revolution). Savitribai's poems reflect the anger of the newly-emerging Indian woman who wanted to be treated as a human being and not just an object of male lust. Savitribai Phule, along with her husband, Jyotiba Phule, played an important role in improving women's rights in India during the British rule. Phule pioneered the campaign for women's education, starting the first school for girls at Pune in 1848 . Savitribai was the first biographer of Jyotiba Phule. She was probably one of the first published women in modern India, and was able to develop her own voice and agency at a time when women of all classes were still treated as less than human, with title to hope for, except to be married as children themselves, bear more children, and live a life of servitude to their husbands.

This paper introduced Savitribai Phule as first feminist philosopher and teacher in colonial India and discusses the relation between women's education and a humane, society based on equality by taking 
Savitribai's radical philosophy with special reference to her collection of poems "KavyaPhule" as its point of departure. It argues that her perspective and her literature are still relevant in a world where education has not reached the girl child across caste and class barriers at a mass level. This paper begins by examining the relation between ethical values, education and women's lives. It proceeds to explore Savitribai's philosophical arguments in this context and concludes by saying that she is a first Indian feminist philosopher in colonial India and arguing for her contemporary relevance.

\section{Introduction}

Savitribai Phule was probably first feminist philosopher in colonial India. She was not a typical passive Indian woman who blindly followed her husband. She is a Mother of women Education and vision of her philosophy is to give freedom to woman from so called Indian tradition. She was a courageous woman who stood by her husband and supported all his radical initiatives. She was a major figure of her time. She was revolutionary in her own right.

Savitribai Phule's Writings:

- Kavya Phule - (1854) (Poetry's Blossom) it is a historical document of the time. She consciously chose the traditional form of writing like abhang, which called a folk form. Her language is simple and effective. While some of her poems are basically nature poems, in others she engages with the themes of education and caste system, exploring people to throw away slavery. No wonder she is regarded as the pioneer of modern Marathi ${ }^{1}$ poetry.

- Bahvan Kashi Subodh Ratnakar (1891) (The Ocean of Pure Gems): Biography of Jyotiba Phule published in 1892. Savitribai's biography was as much about the Maratha history as it was about her husband.

- $\quad$ She also edited four of Jyotiba Phule's speeches on Indian history in 1856. Savitirbai's three letters to Jyotiba spread over twenty years is also a precious and rare piece of literature as women rarely wrote letters in those days, leave alone to their spouses. She discussed social issues in her letters. Savitribai's correspondence is also remarkable because they give us an insight into life and into women's experience of the time.

- $\quad \operatorname{Karz}(\mathrm{Debt})$ her essay on Karz, she condemned the idea of celebrating festivals by borrowing money and thus being burdened by heavy debts. She realized the poor find themselves helpless and unable to change the realities of their lives, either accepted blind faith or got trapped in different ways. She also wrote on addiction, explain how it ruined the lives of the addicted and their families-themes that are still relevant in the $21^{\text {st }}$ century. ${ }^{2}$

Savitribai's literature expressed the pain, ambition and feeling of the modern, liberated Indian woman. While her contemporaries were busy re-constructing the images of the mythological pativrata (faithful to husband) women such as Sita-Savitri module, in contrast, she expressed the passion of modern Indian literature. She was able to develop her own voice and agency at a time when women of all classes were ruthlessly suppressed and lived a secondary-human being existence. She was actively supported and constantly encouraged in this endeavour by her husband and mentor Jyotiba Phule. She was an exemplary role model for the Indian woman during her lifetime and she is and will be a role model for future woman. M.G. Mali her biographer rightly noted her as 'the mother of modern Marathi poetry'.3

A broad analysis of her poems in 'Kavyaphule' (1854) reveals that Savitribai had many sides and shads to her nature and personality. Poem is a one of way of expression. Poem (Kavya) is a piece of writing in which the expression of feelings and ideas is given intensity by particular attention to diction (sometimes involving rhyme), rhythm, and imagery. Poem from Latin poēma, from Greek, variant of poiema something composed, created, from poiein to make. Poem is a way of expression; it has emotional values but also has cognitive values as Savitribai Phule's poems express both kinds of

\footnotetext{
${ }^{1}$ Note: Marathi is a one of the regional language in India (Maharashtra).

${ }^{2}$ Lalita Dhara, Phule's and Women Questions, p. 29.

${ }^{3}$ Dr. M.G.Mali, Savitribai Phule-Samagra Vangamaya, pp. 56.
} 
values. In her poems she addresses social issues like getting an English education, fighting against caste and gender discrimination and problem of untouchability.

The influence of Jyotiba's thought on Savitribai is quite clear in her writings. She had internalized Phule's thought and had the intellectual capacity to understand its significance in society. She seems to be the first person who had understood and assessed Phule's pioneering role in the liberation of the exploited masses. She categorically states in her last poem 'Dialogue at dawn' that Jyotiba is the new dawn on the untouchable's horizon. ${ }^{4}$ Her writings were important both as the strength and product of the social culture of nineteenth century India.

On the opinion of Savitribai Phule a woman has right to become intellectual and only through education woman can become intellectual. Savitribai visualized the dream and philosophy of Phule and became dedicated supporter of his work. In her literature she has repeated the distress, aspirations, and feelings of modern, liberated woman of India. Her composition also reflected to anger of the new emerging woman of India who wanted to be treated as a human being and not just as an object of male-desire.

\section{Jyotiba Phule Father of Indian Social Revolution}

Jyotiba Phule was one of the most important makers of modern India. Phule one of the "Mahatmas' (Great Soul) of India, occupies a unique position among social reformers of Maharashtra in the nineteenth century. He was first teacher of oppressed, critic of orthodoxy in the social system after Buddha and a revolutionary. Dhananjay Keer, his biographer, rightly noted him as 'the father of Indian social revolution.' Women were always at the centre of Phule's thought and action. His philosophical thinking on social and political issues was influenced by Christianity and American thinker Thomas Paine's ideas of 'Rights of Man'. Phule worked towards the abolition of untouchability and started educational institutions for untouchables in the second half of the $19^{\text {th }}$ century. When Pandita Ramabai ${ }^{5}$ converted into Christianity, Phule defended her right to conversion. This had a gender aspect to him. He does not seem to have been particularly in favour of conversion as such but he certainly was in favour of any movement against Brahmanical orthodoxy. That a woman had asserted her right to move away from Brahmin orthodoxy and tyranny was important for him.

In the philosophy of Phule the place of equality and humanity was the most important. He, to develop the qualities of justice, through education wanted equality, freedom and fearlessness. Phule took education for the oppressed and women. It also essential, that it should create the feeling of unity. He experience that women have not got the self-dependence due to the lack of education. He was of the opinion that the development made in society is judged by the extent of education made available to women in society. He was in favor of giving compulsory education to women. Phule fought for the rights of women and work for their emancipation.

\footnotetext{
${ }^{4}$ Lalitha Dhara, (Ed.), Kavya Phule, p.11.

5 Note: Pandita Ramabai (23rd April 1858, 5th April 1922), was High caste Hindu women, was great scholar of Hinduism and also studied Christianity. She was an eminent Indian social reformer and activist. A well known scholar and humanist, ' the greatest woman produced by modern India \& one of the greatest Indians in all history --- the one to lay the foundation for a movement for women's liberation in India. She was a poet, a scholar, and a champion of improvement in the plight of Indian women. As a social reformer, she championed the cause of emancipation of Indian women. A widely traveled lady, she visited most parts of India, and even went to England (1883) and the U.S. (1886-88). She married to Bipin Bihari Medhavi, non-Brahmin a Bengali layer. And this created a stir in the orthodox circle of Hindu society. After a great loss of her husband's death shortly thereafter, she found herself unable to play the role traditionally reserved for upper caste Hindu widows, and converted to Christianity an action which created a scandal even in liberal Calcutta. More liberal verdicts have also bemoaned her conversion as unnecessary.
} 
Phule saw women as the victims of the oppressive, caste-based and rigid hierarchical social system. He believed that socio-cultural forces artificially construct gender relations, especially by Manusmriti ${ }^{6}$ and Hindu tradition. As Simone De Beauvoir observed, "Women are made, they are not born", Phule also raised the question, "Why tradition dishonored woman? In ancient India the position of women does not appear to have been a very happy one. Usually women appear to have been looked upon as inferior to men. And, at times they were considered to be on the same level of the śudras, the lowest of the four castes. Their freedom was extremely restricted. Right in the earliest portions of the canon women is looked upon as something evil that enticed innocent males into a snare of misery. They are described as "the greatest temptation," "the cause of all sinful acts," "the slough," "demons" etc. this mentality regarding women is due to ignorance. Ignorance creates the problems in society. He shows the importance of education in his thought and writings. According to Phule ignorance means darkness and education means sun-light. He realized that for social change education is the effective method and he decided to open the door of education for women and oppressed caste people. Jyotiba has worked for the masses and women made them aware of education as a vehicle for social change.

Jyotiba said, "Without knowledge, intelligence was lost, without intelligence morality was lost and without morality was lost all dynamism! Without dynamism money was lost and without money the shudras sank. All this misery was caused by the lack of knowledge." ${ }^{, 7}$ For him Education is a tool to achieve liberation from ignorance, which is the reason of all sufferings. Jyotiba's philosophy is synthesis of Indian and western thought. Humanism is the lead note in Jyotiba's philosophy and religion. His philosophy is not repetitive but critical, progressive, revolutionary and formative. One of his writings he said:

\section{"Jichya Hati Padnyachi dori tich sansare sambhali"}

\{Who holds (Mother) string of baby's cradle, maintain life of family as well as life society\}

On his opinion woman educated means whole family educated because she nurtured whole family. Phule made a sever attack on tradition which denied genuine rights of women. Phule started a school for untouchables as early as 1848 . He started a school for girls in Pune. Women's education was given ample stress in these schools. The main inspiration to raise the women question in India during this period was from the 'First wave feminism', which was characterized by the demand that women should enjoy the same legal and social rights as men. Its expression can be traced in many feminist works. Phule perceived education as a means for a movement for self-respect and self dependence, and social peace.

He made significant efforts to lead the society on the path of Liberty, Equality and Fraternity. Phule believed in the strength of women and their role in the process of social change and social peace. His initiatives have influenced various spheres of life and transformed the way India today looks at socioeconomic policies, education and affirmative action through socio-economic and legal encouragement. Jyotiba developed a critique of the interrelationship between women's question and patriarchy. He visualized equality and mutual permission as the basis of the man-woman relationship.

\section{Savitribai Phule First Female teacher and feminist Philosopher}

Phule and his wife Savitribai Phule were pioneers of women's education and empowerment in India. Savitribai internalized the vision and way of life of Phule, and was a constant devotee of his work. In the philosophy of Phule the place of equality and humanity was the most important. She, to develop the qualities of justice, through education wanted equality, freedom and fearlessness. She also experiences that women have not got the self-dependence due to the lack of education. She was of the

\footnotetext{
${ }^{6}$ Manusmriti is a text in the Hindu religion believed to be written by Manu (is a author of 'Manusmriti' which lays down the Hindu code of conduct and is believed to be composed in around 1,500 B.C.) which lays down extremely rigorous and discriminatory social norms and dictates for the untouchables ad for women.

${ }^{7}$ Phadke Y.D., Mahatma Phule Samagra Vangmaya), p. 253.
} 
opinion that the development made in society is judged by the extent of education made available to women in society. Therefore she gave her absolute support to her husband who was in favor of giving compulsory education to women. The influence of Jyotiba's thought on Savitribai is quite clear in her writings. She said that...

“...Let knowledge be your God, pursue it all the way

With determination attain success, don't let your mind sway

Knowledge is so precious; it is the greatest gift of all

One with a treasury of knowledge, a wise person people do call." ${ }^{\prime \prime}$

It was the fact that women in nineteenth century India was leading the life of a subordinate-human being. She was considered an object of male-longing. In $19^{\text {th }}$ century education of women $\&$ the lower castes, Phule believed, deserved priority. Hence at home he began educating his wife Savitribai \& opened a girl's school in August 1848 in Pune. The orthodox opponents of Jyotiba were furious \& they started a vicious campaign against him. He refused to be unnerved by their malicious propaganda. As no teacher dared to work in a school in which untouchable were admitted as students, Phule asked his wife Savitribai to teach the girls in his school.

Though, she was previously uneducated, she was encouraged and motivated by Phule to study. Later on she became the first lady teacher of India in the school started by her husband. A building was found in Pune to house the school which started in 1848, with nine students and Savitribai as it headmistress. Phule couple faced severs oppositions from almost all sections of society. Savitribai was subject to harassment everyday as she walked to school. Stones, mud and dirt and dung were fling on her as she passed. She was often abused by groups of men with orthodox beliefs who opposed education for women. She braved this onslaught for many weeks. Her response was, God forgive you. I am doing my duty. May God bless you?" But letter fed up with constant harassment and vicious opposition she almost gave up. But Phule gave her hope, love and encouragement. She went to school wearing an old sari, and carried an extra sari with her to change into after she reached the school. Finally, the pressure on her eased when she was compelled to slap one of her tormentors on the street, after which she was left alone. Later, a peon was employed to escort her to and from the school. ${ }^{9}$ Savitri's courage in withstanding opposition, even physical discomfort, to achieve her goals made her a true life-partner of Jyotiba Phule.

As mentioned in previous section Phule was a visionary who understood the value of education in the empowering of women. He started by sending Savitribai to school and then training her as a teacher to run schools for girls from oppressed communities. In her poem Go, Get Education, ${ }^{10}$ she just expresses the importance of education for women and society and also trying to motivated women in her possible way. As, she is expressing in one of her composition......

Be self-reliant, be industrious

Work, gather wisdom and riches,

All gets lost without knowledge

We become animal without wisdom,

Sit idle no more, go, get education

\footnotetext{
${ }^{8}$ Lalitha Dhara, (Ed.), Kavyaphule, p. 67.

${ }^{9}$ Kavya Phule, p. 27.

${ }^{10}$ Kavya Phuel, Kavya Phule, pp. 36-71.
} 
End misery of the oppressed and forsaken,

You've got a golden chance to learn

So learn and break the chains of caste.

Throw away the Brahman's scriptures fast.

. One of her composition she described the good human being. According to her, "one who looks after his family with care and responsibility, one who is always industrious and inquisitive, who has quest for knowledge, one who is worship of freedom, one who is compassionate towards family, one who is caring, sacrificing and dedicated is truly a good man". In Savitribai's thought Phule was good human and husband and he precisely passed the mission of humanism.

To attain self-reliance let us pledge

And accumulate a wealth of knowledge

Without learning, life is an animal existence, a waste

Don't rest, get an education, make haste

The outcasts can wipe away their woes if they wish

Here's a golden chance to learn English

Learn English and do away with caste discrimination

Cast away the tiresome tales of the Brahmins to damnation ${ }^{11}$

She also tries to explain the reason of sufferings of Indian women and underprivileged class that is ignorance. She said "Work hard, study well, and do well". She constantly underscored the importance of education and physical work for knowledge and prosperity. She felt that women must receive an education as they were in no way inferior to men; they were not slaves of men. She said in one of her composition...

"Just one enemy do we have today

Let's thrash him and drive him away

.Ignorance!"

She also offered one composition where she is giving the message of social peace and also provides the possible way for social harmony. Moral teaching is important as she said in her poem 'Offerings.${ }^{12}$ Her poem has emotional values like love, care and sharing, sacrifice etc but it also has cognitive values, which helps to provide peace in society.

Her writings were an independent expression. Her poetic zeal and literary merits are also beyond any doubt and debate. Her writings demonstrate the influence of folk songs, Bhakti poetry (devotional poetry) and the Shairi (ballad literature) form. Though she selected traditional forms of writing, she constantly propagated modern values such as humanism, liberty, equality, brotherhood and rationalism through her writings. Her composition Kavya Phule reveals moral teaching where she is offering ethical values emotional as well as cognitive values listed as follows...

\footnotetext{
${ }^{11}$ Kavya Phule, pp. 36-71.

${ }^{12}$ Note: 'Offerings' is one of her composition which I have quote in the beginning of this work. Kavya Phule is a compilation of almost 41 poems written by Savitribai Phule.
} 


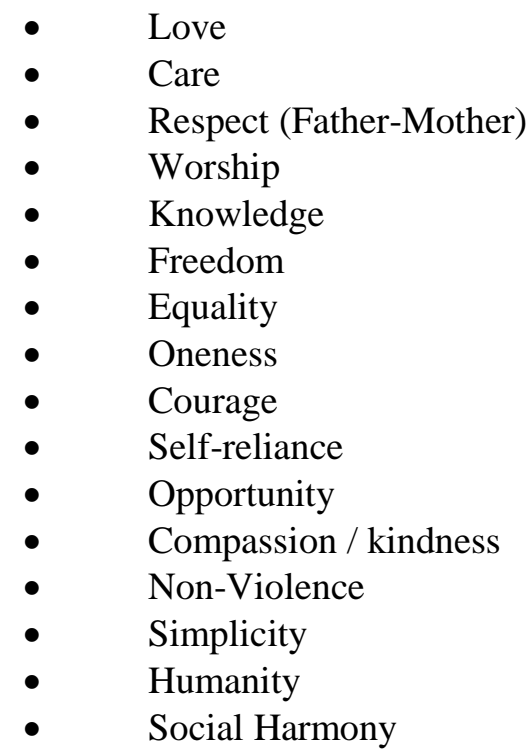

Here I would like to compare moral philosophy Savitribai with moral philosophy of Greek philosopher Aristotle. Aristotle has discussed virtue ethics in his literature on ethics. Virtue ethics as discussed by Aristotle focus on three essential concepts; they are virtue, moral wisdom and happiness. Aristotle has talked about the practical virtues of social life, List of virtues given by Aristotle as follows: ${ }^{13}$

$\begin{array}{ll}\text { - } & \text { Courage } \\ \text { - } & \text { Temperance } \\ \text { - } & \text { Liberty } \\ \text { - } & \text { Magnificence } \\ \text { - } & \text { Proper ambition } \\ \text { - } & \text { Good temper } \\ \text { - } & \text { Truthfulness } \\ \text { - } & \text { Fittiness } \\ \text { - } & \text { Mondliness } \\ \text { - } & \text { Righteous indignation }\end{array}$

In Aristotle's ethics, where he describes a virtue unknown to us, but which he regarded as one of the highest. As Aristotle Savitribai also accept courage, liberty, friendliness, modesty, wisdom in her list. If life is to be worth living, he argues, it must surely be for the sake of something that is an end in itself i.e., desirable for its own sake, is Happiness. If we study moral values given by Aristotle and Savitribai Phule we can see similarities. Moral values of human life given by both Savitribai and Aristotle have only one final goal of life that is social peace, harmony in society. Their moral philosophy is human centric and their vision of ethical philosophy is humanism. So we can see Savitribai was also influenced by western ideas of ethics and morality.

\section{Savitribai Phule: Social Reformer}

Savitribai not only worked as an educational reformer but also worked as social reformer, especially for women. She was not only great teacher and philosopher of India but also true companion and great supporter of her husband Jyotiba Phule who made this endeavour possible for women and underprivileged class people of India to get education use the principles like equality and freedom and

${ }^{13}$ Bourke, J. Vernon, History of Ethics, Vol. 1, P. 46. 
fight for our own rights in society. $19^{\text {th }}$ century India was very backward with the caste system taking ugly forms. Untouchability and $\mathrm{Sati}^{14}$ system were still in practice, and the illiteracy was very high. Education was denied to the women, and lower caste society. They were treated as chattels, providing domestic, economic and sexual labour in their family surroundings. There was no public role for them in society. They were not allowed to express their opinion or come together in society. They were not given any education and had to follow strict decorum in their homes. Child marriages were a norm and widows were banished from society and had little rights. It was a male dominated society and women were treated as second class citizens. However, this period witnessed the rise of social reform movements in India, especially relating to women emancipation like the abolishment of Sati and the initiate of widows remarriage. It is obvious that $19^{\text {th }}$ century India was not women's age it is supposed to be the 'dark age' for them.

Phule couple introduced a new image of religion which was known as universal religion. Phule's theological thought was summarized by his colleague and follower, Dr. Vishram Ghole: "Phule taught the people to think of religion in terms of what is right and wrong and above all in terms of cause and effect. He placed before them an account of current customs and beliefs in terms of their validity. He attacked idol-worship and made the cause for monotheism." 15 Phule's social thoughts are based on humanism. Phule founded the Satyashodhak Samaj (Society of Truth Seekers) as a socio-spiritual movement on September 24, 1871. It is based on the values like equality, Justice and tranquility. He spread value based system through his work and thought. His philosophy was human centric. Jyotiba Phule wanted lower castes to exploit the opportunity and get rid of the tyranny of Brahmins. Savitribai headed SatyashodhakSamaj after Mahatma Phule's death, and broke new ground in socio-cultural creativity. Moto of Satyashodhak Samaj was to Liberalize, Equalize and Modernalize not only member of society but every people of India. Savitribai headed the women's unity of the Satyashodhak Samaj. The objective of the society was "to give freedom to shudras and ati-shudras (Untouchable peoples) from the tyranny of the Brahmanical scriptures and tradition, teach them their human rights and liberate them from mental and religious slavery. In the draught of 1896, Savitribai worked ceaselessly, and brought pressure on the government to undertake relief measures.In1897, an epidemic of plague swept Pune. Savitribai once again engaged personally in the relief effort. Unfortunately, she caught the disease and died on $10^{\text {th }}$ march, 1897.

Prof. Hari Narake wrote in Mahatma Phule Gaurav Granth, "More than Jotirao, his wife deserves praise. No matter how much we praise her, it would not be enough. How can one describe her stature? She cooperated with her husband completely and along with him, faced all the trials and tribulations that came their way. It is difficult to find such a sacrificing woman even among the highly educated women from upper castes. The couple spent their entire lifetime working for people." Braj Ranjan Mani also writes, "Savitribai Phule struggled and suffered with her revolutionary husband in an equal measure, but remains obscured due to casteist and sexist negligence. Apart from her identity as Jotirao Phule's wife, she is little known even in academia. Modern India's first woman teacher, a radical exponent of mass and female education, a champion of women's liberation, a pioneer of engaged poetry, a courageous mass leader who took on the forces of caste and patriarchy certainly had her independent identity and contribution. It is indeed a measure of the ruthlessness of elite-controlled knowledge-production that a figure as important as Savitribai Phule fails to find any mention in the history of modern India. Her life and struggle deserves to be appreciated by a wider spectrum, and made known to non-Marathi people as well."16

\footnotetext{
${ }^{14}$ Sati is an old, largely defunct custom, among some communities. The ritual of dying at the funeral pyre of the husband is known as "Sati". According to some of the Hindu scriptures women dying at the funeral pyre of her husband go straight to heaven so it's good to practice this ritual. Initially it was not obligatory for the women but if she practiced such a custom she was highly respected by the society. Sati was considered to be the better option than living as a widow as the plight of widows in Hindu society was even worse. (Archana Malik-Goure, Jyotiba Phule: A Modern Indian Philosopher, p 36)

${ }_{15}$ G.P. Deshpande, "Selected works of Jotirao Phule", P. 225.

16 'A Forgotten Liberator', the life and struggle of Savitribai Phule, p. 28.
} 


\section{Conclusion}

Teaching philosophy of feminism to post graduate students in the class room is really a good experience. Indian Society does not take women seriously, as intellectuals. We teach feminist philosophers in our curriculum and it's really interesting to discuss in class which I feel very important and practical issue of human life should be discussed. There is scope in class-room discussion to share others experience including our own experience as a women, as a member of society. Because the issue of women is not just something metaphysical, it is practical thing and everybody has their own experience of life. Not necessary as an individual but as a member of the society. I realized that during discursion present generation and also privileged class of the society are not aware about problems related to women in $19^{\text {th }}$ century India.

This discursion is really important on feminism because we have to bring women into discipline of philosophy. Feminist philosophers like Savitribai Phule have different philosophy of life; they have different summum bonum, highest goal in their philosophy. Her goal of life was freedom from Indian tradition, freedom from religious tyranny and rituals. Savitribai Phule wanted to introduce practical philosophy of human being, individual growth from education; other unethical things she was rejecting like so called Indian tradition. In her philosophy she was talking about individual growth, love, care and humanism as virtue, her emphasis on self-reliance and wants to interpret Indian tradition in her own way. They fought against the tradition and fought for human rights, rights of education and rights of human development. She took a extremely innovative stand in her whole life.

By studding feminist thinkers in the Contemporary Indian philosophy curriculum, future generation can learn the relevance of a gender sensitive approach to treating women as equals. This is enshrined in the constitution of Indian. The Constitution of India gave women equal rights with men from the beginning. Unfortunately, women in this country are mostly unaware of their rights because of illiteracy and the oppressive tradition in some parts of India. Gender discrimination still persists in India and lot more needs to be done in the field of women's education in India.

I would like to conclude with that, the development of any nation depends upon the educational growth. Nation forms its skeleton through equal contribution of both men and women educational status. The constitution of India and the legal codes bestowed upon women the privileged of equal rights with men. The same facilities of education and the same opportunities of profession and employment are available for women. In the modern age, hierarchy between men and women has been explicitly questioned with rise of women's liberation movements all over the world. As a result women are quite confident of their ability to achieve their goals in this life. Today we find that women have proved to be quite otherwise and are holding highest positions in every field of life. I Thanks to all feminist philosopher who introduced philosophy of education and philosophy of humanism.

\section{References:}

1. B.R Mani \& P Sardar, (Ed.) (2008), A Forgotten Liberator', the life and struggle of Savitribai Phule, Mountain Peak, New Delhi.

2. Dhara, Lalitha, (Ed.), (2011), Phule's and Woman's Question, Dr. Ambedkar college of Commerce and Economics, Mumbai.

3. Dhara, Lalitha, (Ed.), (2012), Kavya Phule, Dr. Ambedkar college of Commerce and Economics, Mumbai.

4. Guthrie, W.K.C., (1967), The Greek Philosophers From Thales to Aristotle,' Methuen and Co. Ltd., London.

5. Huby, P., (1969), Greek Ethics, Macmillan, St. Martin Press, London.

6. Joshi, Laxman Shastri, (1996), Jotirao Phule, National Book Trust, New Delhi.

7. Keer, Dhananjay, (1997), Mahatma Jotirao Phooley, Father of the Indian social revolution, Popular Prakashan. Mumbai.

8. Malik-Goure, Archana, (2013), Jyotiba Phule: A Modern Indian Philosopher, Suryodaya Publication, New Delhi. 
9. Mali, M.G., (2006), Savitribai Phule-Samagra Vangamaya, Maharashtra Rajya Sahitya Sanskriti Mandal, Mumbai.

10. Phadke, Y.D. Editor, (1991), .Mahatma Phule Samagra Vangmaya, Publisher Maharashtra Rajya Sahitya and Sanskruti Mandal, Mumbai.

11. Omvedit, Gail, (Ed), (2002), Jyotiba Phule Ani Stree Mukticha Vichar, Lokvangmay group, Mumbai.

12. Rao, Anupama (Ed.), (2003) Gender and Caste, series Issues in Contemporary Feminism, Kali for Women", New Delhi. 